\title{
Fracture-controlled gas hydrate systems in the northern Gulf of Mexico
}

\author{
Ann E. Cook ${ }^{\mathrm{a}, *}$, Dave Goldberg ${ }^{\mathrm{a}}$, Robert L. Kleinberg ${ }^{\mathrm{b}}$ \\ ${ }^{a}$ Lamont-Doherty Earth Observatory of Columbia University, Palisades, NY 10964, USA \\ ${ }^{\mathrm{b}}$ Schlumberger-Doll Research, Cambridge, MA, 02139, USA
}

\section{A R T I C L E I N F O}

\section{Article history:}

Received 6 February 2007

Received in revised form 21 June 2007

Accepted 31 January 2008

\section{Keywords:}

Gas hydrate

Ocean drilling

Fracture

Gulf of Mexico

\begin{abstract}
A B S T R A C T
High-angle, open mode fractures control the presence of natural gas hydrate in water-saturated clays at the Keathley Canyon 151 site in the northern Gulf of Mexico, which was investigated for gas hydrates as part of the Chevron Joint Industry Project drilling in 2005. We analyze logging-while-drilling resistivity images and infer that gas hydrate accumulated in situ in two modes: filling fractures and saturating permeable beds. High-angle hydrate-filled fractures are the most common mode for gas hydrate occurrence at this site, with most of these fractures dipping at angles of more than $40^{\circ}$ and occurring between 220 and $300 \mathrm{~m}$ below seafloor. These fractures all strike approximately $\mathrm{N}-\mathrm{S}$, which agrees with the $165^{\circ} \mathrm{SE}-345^{\circ} \mathrm{NW}$ maximum horizontal stress direction determined from borehole breakouts and which aligns with local bathymetric contours. In one interval of hydrate-filled fractures, porosity increases with increasing hydrate saturation. We suggest that high pore pressure may have dilated sediments during fracture formation, causing this increase in porosity. Furthermore, the formation of gas hydrate may have heaved fractures apart, also increasing the formation porosity in this interval.
\end{abstract}

(c) 2008 Elsevier Ltd. All rights reserved.

\section{Introduction}

Specific low temperature and elevated pressure conditions dictate the stability of natural gas hydrate. Gas hydrate forms from a combination of water and natural gas, and can be found in the marine sediment along many continental margins (Kvenvolden and Barnard, 1982). On seismic sections the base of the gas hydrate stability zone (GHSZ) may be indicated by a strong negative polarity reflector known as a bottom-simulating reflector or BSR (Markl et al., 1970). The distribution of gas hydrate within the GHSZ is highly variable and depends on sediment type, gas flow, and tectonic regime.

Recently, several studies have suggested that natural gas may migrate through the GHSZ along faults, fractures, and/or other high permeability conduits (Hornbach et al., 2004; Nimblett and Ruppel, 2003; Tréhu et al., 2004). Several authors have proposed that hydrate-filled fractures may either be the primary locus of hydrate accumulation in marine sediment or hydrate-filled relics of the conduits that fed natural gas into what are now laterally extensive hydrate-bearing beds (Kleinberg, 2008; Milkov and Sassen, 2001; Nimblett and Ruppel, 2003; Sassen et al., 2001; Sassen et al., 1999). Weinberger and Brown (2006) found complicated fracture networks to be the primary method of fluid flow for natural gas and an

\footnotetext{
* Corresponding author. Tel.: +1 845365 8796; fax: +1 8453653182.

E-mail addresses: acook@ldeo.columbia.edu (A.E. Cook), goldberg@ldeo. columbia.edu (D. Goldberg), kleinberg@slb.com (R.L. Kleinberg).
}

important mode of gas hydrate accumulation at Hydrate Ridge, offshore Oregon. These hydro-fracture networks were found to be oriented parallel to the maximum horizontal stress direction $\left(\mathrm{S}_{\mathrm{Hmax}}\right)$ determined from borehole breakouts in logging-whiledrilling (LWD) images (Goldberg and Janik, 2006).

In this paper, we infer the distribution and location of gas hydrate using LWD resistivity images from Hole KC151-2 drilled in the Keathley Canyon area of the northern Gulf of Mexico and analyze the associated stress field. The results are used to describe in greater detail the open mode fracture system that was found to control gas hydrate occurrences in this area (Claypool, 2006).

\section{Geologic setting}

In 2005, the Chevron Joint Industry Project (JIP), cosponsored by the U.S. Department of Energy (DOE), drilled two holes at Site KC151 in Keathley Canyon in the northern Gulf of Mexico (Fig. 1). Hole $\mathrm{KC} 151-2\left(26.8229^{\circ} \mathrm{N}, 92.9864^{\circ} \mathrm{W}\right)$ was drilled and logged using LWD tools. Hole KC151-3, located 10 m from KC151-2, was cored and wireline logged. For the purposes of this paper, Hole KC151-2 will be referred to as Hole 2 and Hole KC151-3 will be referred to as Hole 3.

The Gulf of Mexico is a passive margin basin with a large continental shelf and a gradually dipping continental slope. From late Cretaceous through Pleistocene time, the Gulf of Mexico experienced massive deltaic sedimentation from North American rivers. The underlying Jurassic salt began to deform and mobilize 


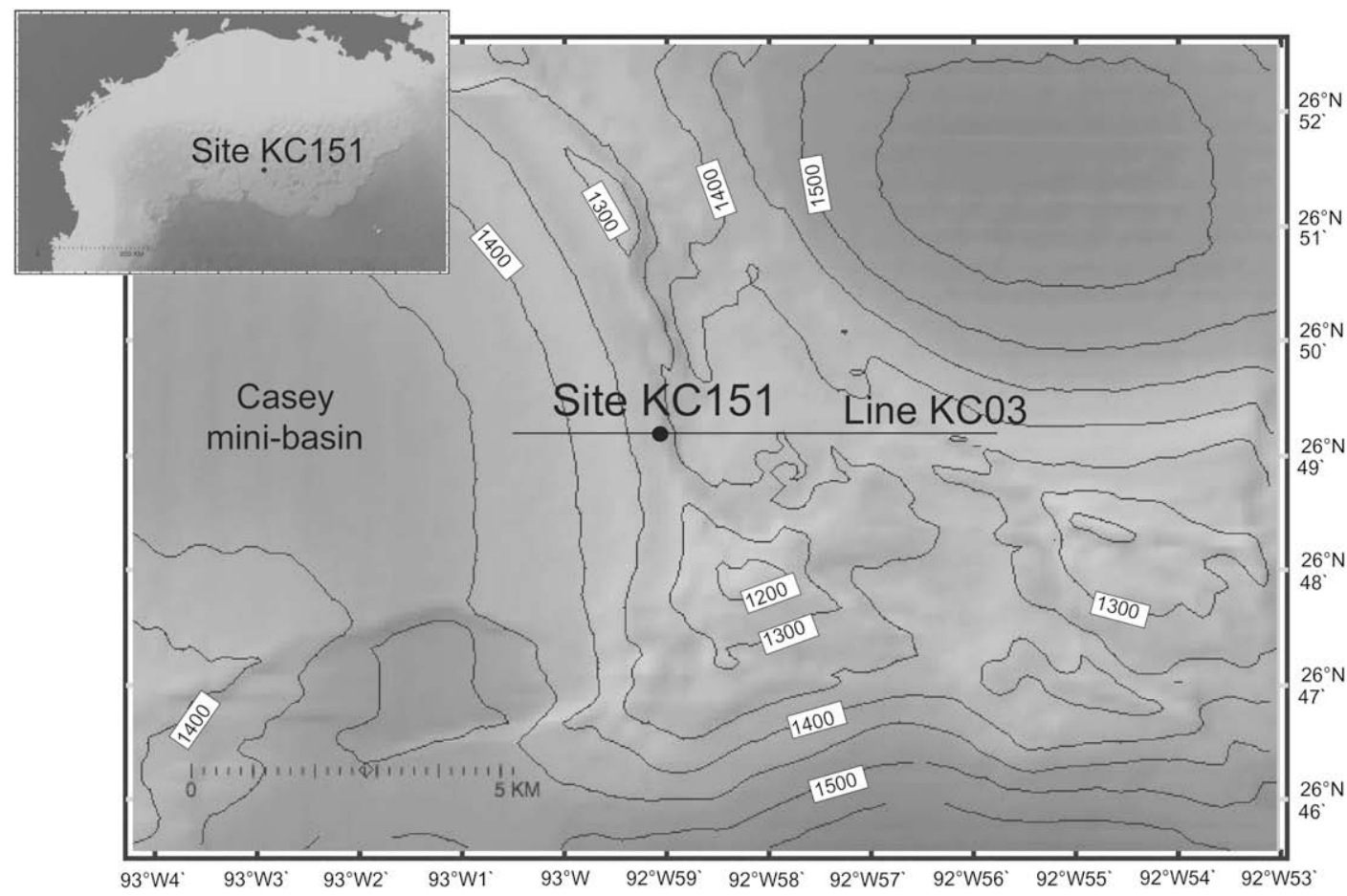

Fig. 1. Location of Keathley Canyon Site KC151 on the northern continental slope in the Gulf of Mexico.

under the weight of the accumulating sediment, resulting in structural deformation of the overlying sediment (Woodbury et al., 1973).

The holes drilled at Site KC151 lie on a subtle bathymetric high at the edge of a mini-basin at water depths of $1320 \mathrm{~m}$ and $1335 \mathrm{~m}$. Salt movement and deformation led to the formation of the mini-basin, which lies to the west of Site KC151 (Fig. 1). The mini-basin formed as sediment preferentially loaded the area west of Site KC151, causing the underlying Jurassic salt to deform and flow to the east of Site KC151, as seen on W-E trending USGS seismic line KC03 (Fig. 2; Hutchinson and Hart, 2004). As the salt migrated eastward, more sediment was deposited in the depression, perpetuating the formation of the mini-basin. The salt formation can be seen east of the drill site on the seismic line, highlighted by the characteristic loss of reflective detail in the seismic section. More detail about the stratigraphic and tectonic evolution of this area is given by Hutchinson et al. (2008).

Salt withdrawal mini-basins are well documented in the northern Gulf of Mexico (Beauboeuf and Friedmann, 2000; Nelson, 1991; Prather et al., 1998; Pratson and Ryan, 1994) and appear as localized, circular to elliptical depressions on the seafloor (Prather et al., 1998). The Casey mini-basin, the feature near site KC151 has been described (Hutchinson et al., 2008). appears towards the west and is $\sim 10 \mathrm{~km}$ in diameter (Fig. 1). In cross section, the mini-basins have symmetric internal structure and are flanked by massive salt walls (Prather et al., 1998). Fig. 2 highlights the internal structure of the mini-basin, notably the high and low amplitude sediment draping the depocenter. Such thin, continuous hemipelagic drape complexes are composed of detrital sediments, which slowly settle from the water column (Beauboeuf and Friedmann, 2000). Ponded onlapping features pinch out towards the edge of the mini-basin. Turbidite layers and mass transport complexes (gravity-induced or downslope deposits) are also common features in mini-basins that deposit quickly and have variable thicknesses (Moscardelli et al., 2006). They appear on USGS seismic line KC03 (Hutchinson and Hart, 2004) as low-amplitude, semi-transparent, chaotic reflections.
Spot coring in Hole 3 recovered sediments composed primarily of very soft to very stiff olive-gray clay, with a few sand- and silt-rich pockets (Hippe et al., 2006). Age dating of the sediment was not performed on the cores from Hole 3. However, extensive stratigraphic analysis by Hutchinson et al. (2008) concludes that the shallow sediments drilled at Site KC151 are Pleistocene and Holocene age.

\section{Log data}

\subsection{Hole 2}

Hole 2 was drilled to 459 mbsf using LWD tools that collect conventional well log data as well as borehole image data. Fig. 3 displays the caliper, gamma ray, ring resistivity, and density logs acquired in Hole 2. The caliper measures the diameter of the borehole. From 0 to $115 \mathrm{mbsf}$, the hole is enlarged by $\sim 2.5$ to $7.5 \mathrm{~cm}$ from the standard $21.5-\mathrm{cm}$ diameter, resulting in lower data quality in this interval. The most extreme enlargements occurred from 100 to 115 mbsf, which correlates to a sandy clay unit described in the logging report for Hole 3 (Claypool, 2006). The gamma ray log values dip by $\sim 40$ API in the $100-115$ mbsf interval, indicating a more sandy layer. Below $115 \mathrm{mbsf}$, the gamma ray log displays relatively constant API values, indicating that clay content and lithology is fairly uniform below this depth. Sparse spot cores from Hole 3 also indicate fairly constant lithology downhole (Hippe et al., 2006).

From 115 to $459 \mathrm{mbsf}$, the borehole geometry is relatively smooth and regular, which yields high quality log readings. Density values are normal for unconsolidated marine clays. The density log shows a characteristic small, gradual increase with depth, likely due to the slow compaction of clays with burial (Hamilton, 1976). Resistivity values are typical for shallow marine sediment, ranging from 1 to $3.5 \Omega \mathrm{m}$. A high resistivity interval occurs between 220 and 300 mbsf, and may contain gas hydrate. 


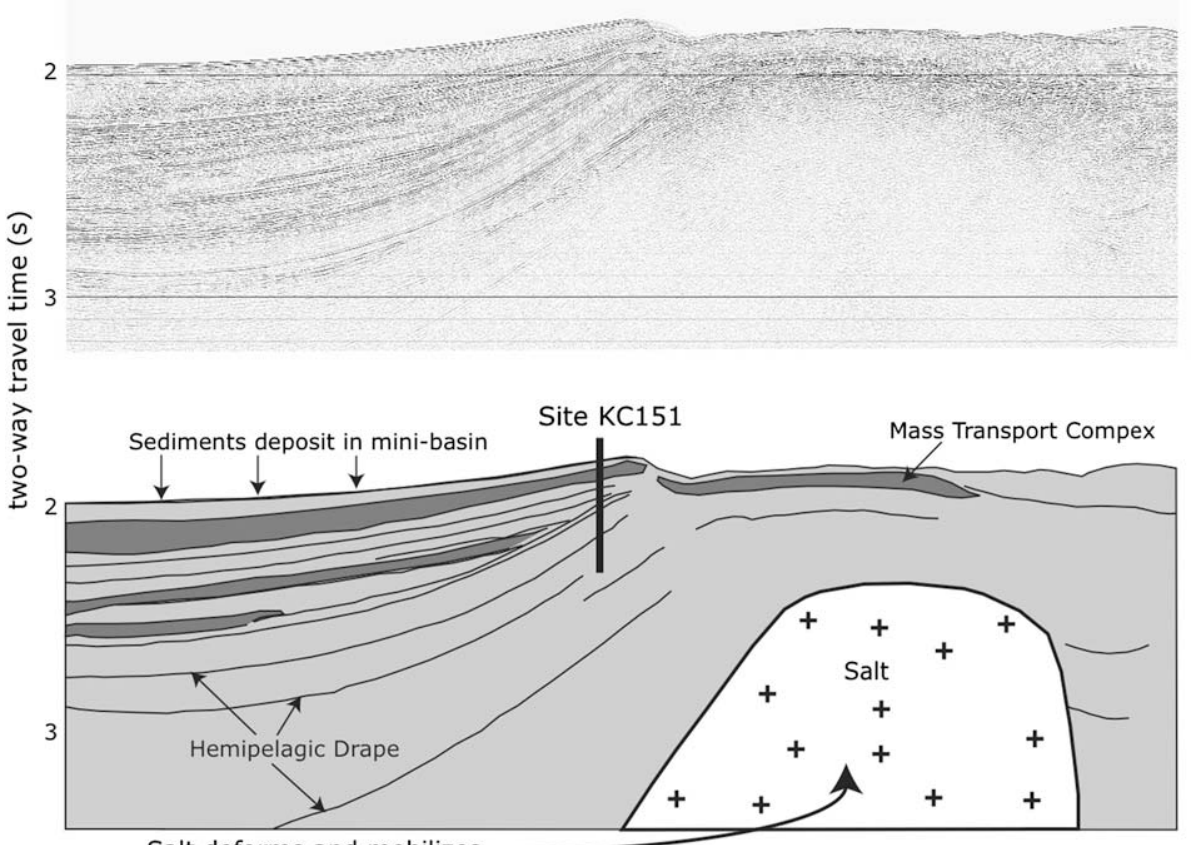

Salt deforms and mobilizes

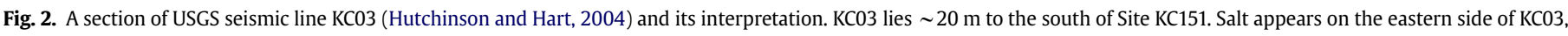

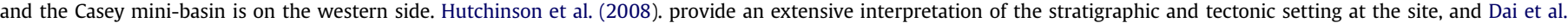
(2008) give interpretations of the stratigraphic section and seismic features in terms of high-stand and low-stand systems tracts.

\subsection{Hole 3}

Approximately $10 \mathrm{~m}$ from Hole 2, Hole 3 was cored and logged with wireline tools to a total depth of $444 \mathrm{mbsf}$. Conditions in Hole
3 were arguably poorer at the time of logging than in Hole 2 because a longer period of time elapsed between drilling and logging. The quality of the wireline logs collected in Hole 3 is indeterminate because (1) no caliper log was recorded in this hole,
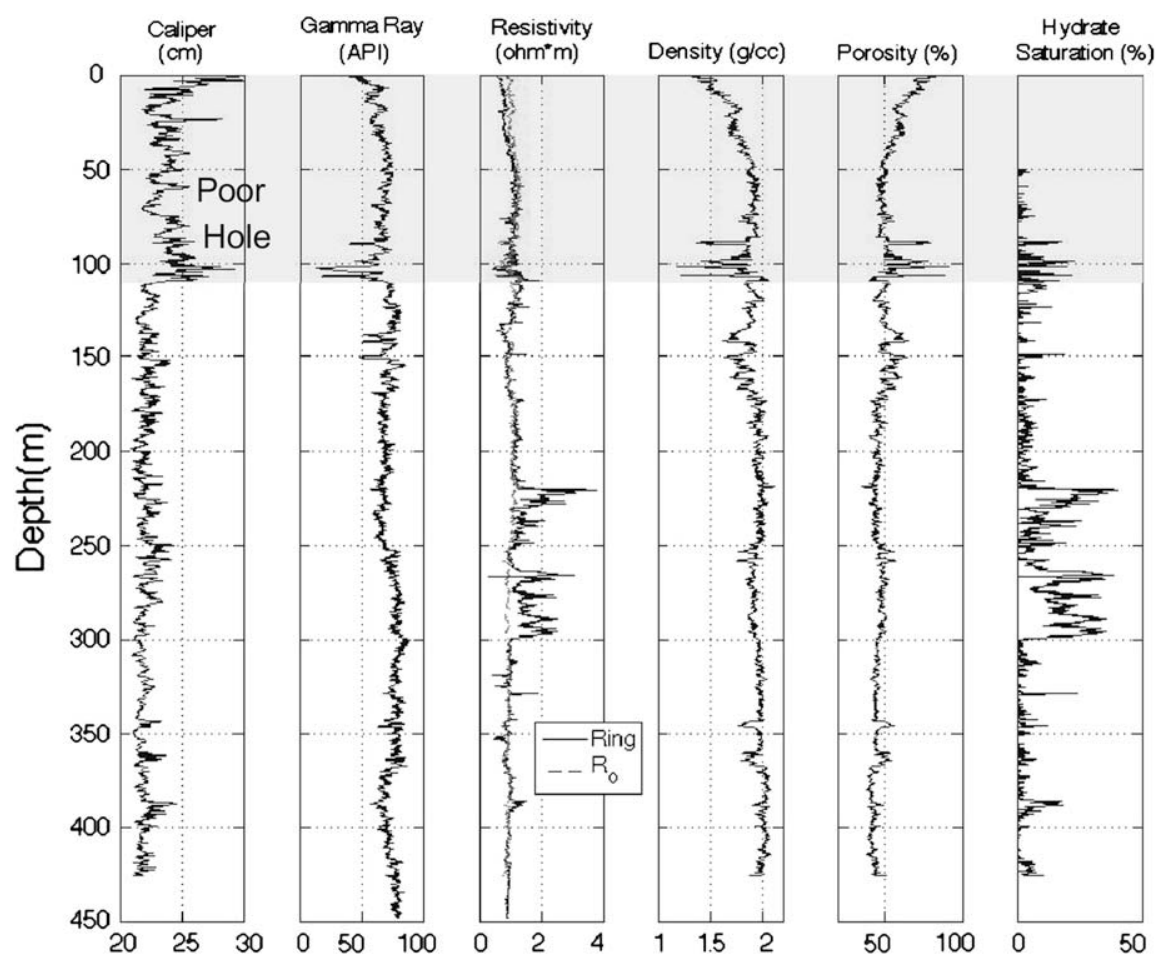

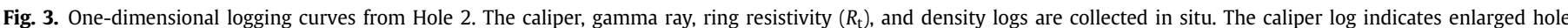

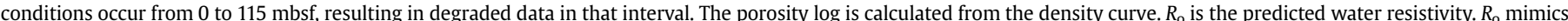
Ring in water saturated intervals and deviates in hydrate saturated intervals. The ratio of $R_{0}$ to Ring yields the hydrate saturation (Eq. (2)). 
and (2) the only log data in common between Holes 2 and 3 - the gamma ray log - displays a weak correlation between holes (Fig. 4). In general, data from holes drilled close together at the same site should be easily correlated. However, the complex structural and lithologic relationship occurring at site KC151 render hole-to-hole depth correlation of the gamma ray logs difficult in this case.

In this paper, we use the downhole-measured temperature gradient, the salinity and density measurements on the cores, and lithology descriptions of the cores recovered from Hole 3. In situ measurements determine a temperature gradient of $3{ }^{\circ} \mathrm{C} / 100 \mathrm{~m}$ (Claypool, 2006). Salinity measured from pore water in cores averaged 45 ppt, with a maximum of 55 ppt (Kastner et al., 2008). The base of the GHSZ is estimated to be approximately $350 \mathrm{mbsf}$, based on a phase stability curve that accounts for the high salinity seen in Hole 3 (Tishchenko et al., 2005).

\subsection{Indications of gas hydrate}

Gas hydrate is an electrical insulator, meaning that an increase in resistivity is measured in hydrate saturated sediments. Because no gas hydrate was recovered at Site KC151, we consider three alternative scenarios to determine if gas hydrate is the cause of the resistivity increase observed in Hole 2, an issue also discussed by Lee and Collett (2008). In shallow hemipelagic clays, a measured increase in resistivity may be due to a change in lithology, the presence of free gas, and cementation or compaction of the sediment. The gamma ray log from Hole 2 and available sediment core information from Hole 3 suggests

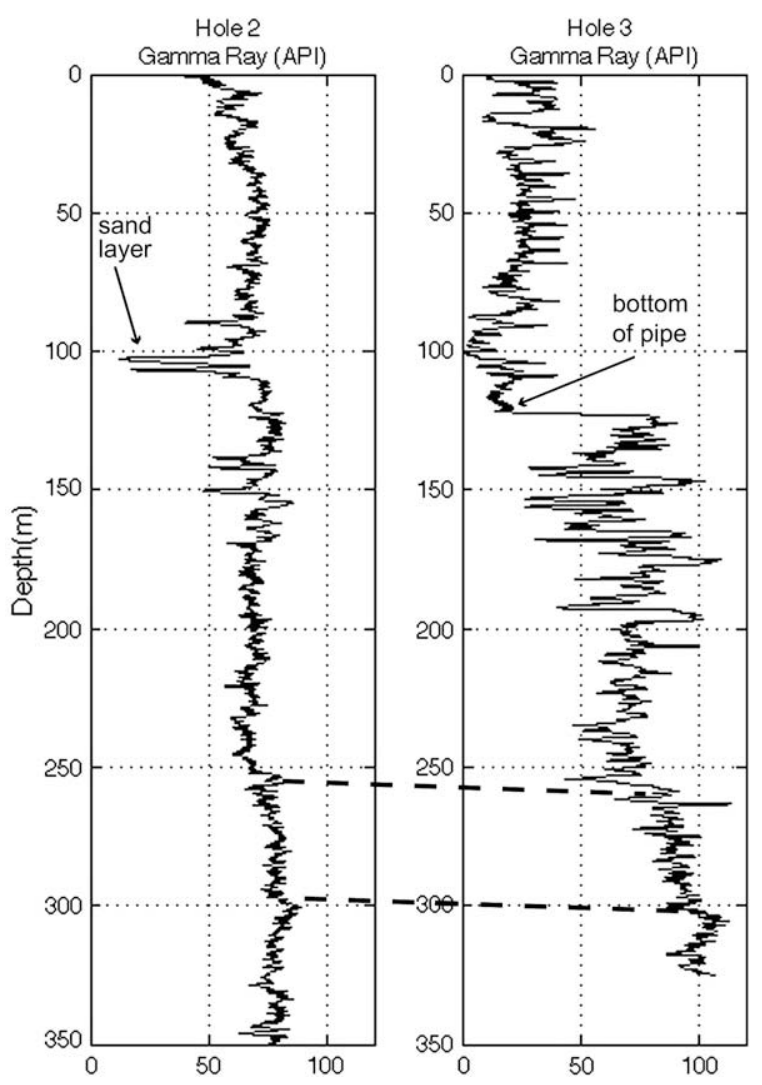

Fig. 4. Gamma ray curves from Hole 2 and Hole 3 . The curves show very little correlation. Black tie lines indicate two points, which may correlate hole-to-hole. This suggests Hole 2 and Hole 3 are offset by $10-15 \mathrm{~m}$, a significant offset considering the holes are $\sim 10 \mathrm{~m}$ apart. that the observed resistivity increase is not due to a lithology change.

If free gas is present within the GHSZ, changes should be seen on two logs: the density-derived porosity and the neutron porosity logs. The density-derived porosity, which is considered to be an accurate estimate of in situ porosity in clays, is calculated using:

$\phi_{\text {den }}=\frac{\rho_{\mathrm{g}}-\rho_{\mathrm{b}}}{\rho_{\mathrm{g}}-\rho_{\mathrm{w}}}$

where $\rho_{\mathrm{b}}$ denotes in situ density, $\rho_{\mathrm{g}}$ represents the density of sediment grains, and $\rho_{\mathrm{w}}$ is the density of pore water. We assume $\rho_{\mathrm{g}}=2750 \mathrm{~kg} \mathrm{~m}^{-3}$ based on specific gravity measurements made on sediment cores from Hole 3 (Hippe et al., 2006) and adopt average water density of $1040 \mathrm{~kg} \mathrm{~m}^{-3}$. Lee and Collett (2008), Dai et al. (2008), and Dugan (2008) use slightly different values for these densities. Variation of a few percent in the adopted density values do not have a major effect on our interpretations.

The neutron porosity log, which measures hydrogen density, is not considered a reliable indicator of in situ porosity in unconsolidated clays. This measurement responds to hydrogen in clay minerals as well as clay bound water, yielding porosity estimates higher than the in situ porosity. The neutron porosity log can still be used as a gas indicator, however. In zones saturated with free gas, which has a lower hydrogen density than pore water, the neutron porosity will significantly decrease. In contrast, the density-derived porosity log yields a higher porosity estimate in free gas intervals because the density of gas is much lower than the density of the pore water. Fig. 5 displays both the neutron porosity $\log$ and the density porosity log from 180 to $310 \mathrm{mbsf}$. Throughout the interval, the clay effect can clearly be seen; the neutron porosity $\log$ is about 5 porosity units (i.e. $5 \%$ of total bulk volume) higher than the density-derived porosity log. The average for each log over the $180-310$ mbsf interval is also calculated. If free gas were affecting the log responses, the neutron porosity log should decrease below the average values, and the density porosity log should increase above average values in the high resistivity intervals. Because both porosity logs follow a similar pattern with depth, it is very unlikely free gas is present in this interval.

Cementation and compaction of sediments result in a reduction of porosity and an increase in bulk density, as well as an increase in formation resistivity. A resistivity increase that correlates to a density increase may be attributed to cementation and compaction. The resistivity increases in Hole 2 are not associated with a density increase, and thus, it is unlikely that the resistivity increase is due to the cementation and compaction of sediments.

\subsection{Gas hydrate saturation}

Gas hydrate saturation, $S_{\mathrm{h}}$, can be calculated using Archie's equation (Collett and Ladd, 2000). Archie's equation assumes the measured resistivity $R_{\mathrm{t}}$ is a function of the water resistivity, the sediment resistivity, and an insulator in the pore space (Archie, 1942). The pore space insulator in this case is gas hydrate. Sediments must be water-wet in order for Archie's equation to be applicable, as is the case for marine sediments (e.g. Murray et al., 2006). In shales or clay-rich sediments, modifications of Archie's equation are often used because clay-associated ions are thought to contribute to the measured conductivity. Erickson and Jarrard (1998) determined that shallow, high-porosity water saturated clays do not display any conductivity increase due to clay content and that it is appropriate to apply Archie's equation without modification. However, Archie's equation must be used with caution in fractured media. 

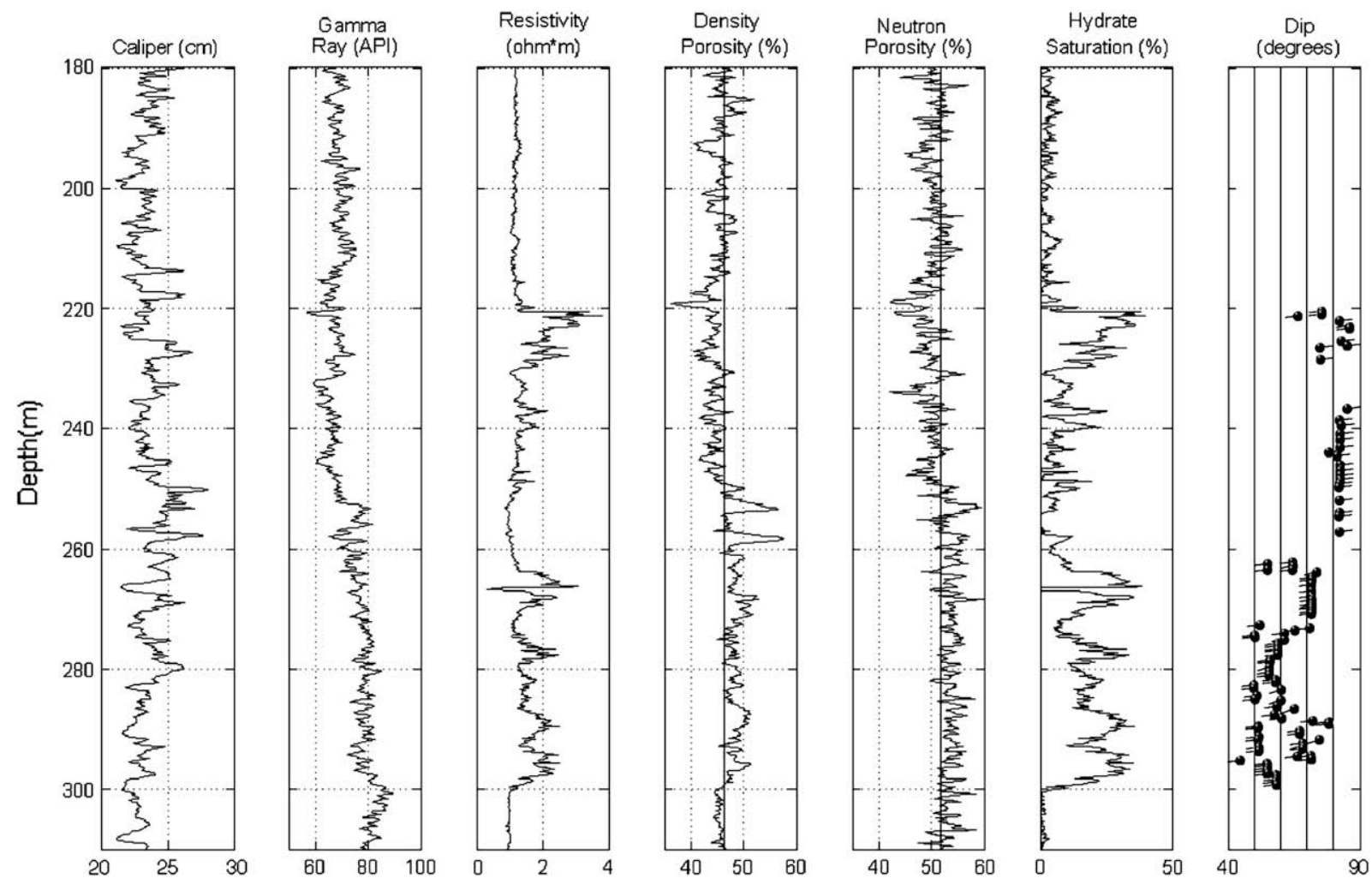

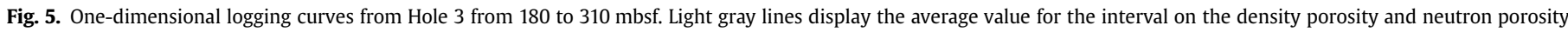

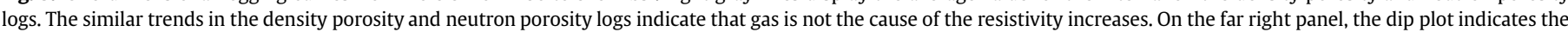
angle of the dipping fracture with a gray dot. The black tail indicates the dip direction. All fractures in this hole dip to the east (right) or to the west (left).

Thus, we compute hydrate saturation using Archie's equation for the simple homogeneous case, as follows:

$S_{\mathrm{h}}=1-\left(\frac{a R_{\mathrm{w}}}{\phi^{m} R_{\mathrm{t}}}\right)^{1 / n}=1-\left(\frac{R_{\mathrm{o}}}{R_{\mathrm{t}}}\right)^{1 / n}$,

where $R_{\mathrm{t}}$ is the measured resistivity, and $R_{\mathrm{W}}$ is calculated from the salinity and temperature gradient measured from Hole 3 . The cementation exponent $n$ was estimated to be 2.4 for marine muds (Malinverno et al., 2008). Values for $a$ and $m$ are calculated by fitting the water-saturated resistivity curve $\left(R_{0}\right.$ in Eq. (2)) to the measured $R_{\mathrm{t}}$ curve in water saturated intervals. The best-fit values of $a$ and $m$ are those that give the smallest squared misfit between $R_{\mathrm{o}}$ and $R_{\mathrm{t}}$. In Hole 2, we used $120-215 \mathrm{mbsf}$ and $305-410 \mathrm{mbsf}$ as the water saturated intervals, avoiding intervals of degraded borehole or suspected hydrate show. For Hole 2, $a=2.19$ and $m=1.22$. In Fig. 3 it can be clearly seen that $R_{0}$ reproduces $R_{\mathrm{t}}$ in the water-saturated intervals; $R_{\mathrm{t}}$ deviates from $R_{\mathrm{O}}$ in the hydratesaturated intervals (from 220 to $250 \mathrm{mbsf}$ and from 260 to $300 \mathrm{mbsf}$ ). The ratio of $R_{\mathrm{o}}$ to $R_{\mathrm{t}}$ determines the hydrate saturation.

\section{Image analysis}

\subsection{Resistivity images from Hole 2}

The geoVISION ${ }^{\mathrm{TM}}$ tool (GVR6) is an LWD tool that records continuous $360^{\circ}$ oriented measurements of the downhole resistivity while drilling. These measurements produce images of the nearwellbore environment. Shallow, medium and deep button electrodes lie longitudinally along the surface of the tool and measure nominally $2.5,7.65$ and $12.7 \mathrm{~cm}$ deep into the formation, respectively. All buttons have a vertical resolution between 5 and $7.5 \mathrm{~cm}$. The GVR6 performs best in $21.5-\mathrm{cm}$ diameter hole. The resulting GVR6 button images have an azimuthal resolution of $\sim 6^{\circ}$ (Bonner et al., 1996). GVR6 measurements are made just a few minutes after drilling, allowing little time for such in situ changes as dissociation of gas hydrate or degradation of the hole condition. However, formation anisotropy, such as high angle fracturing, can cause variability in LWD resistivity measurements.

Two types of normalization enhancements are performed on image data during processing. Static normalization enhances the entire image interval by binning each resistivity value into 256 color levels, scaled to the high and low resistivity values from that particular data set. This technique best exhibits large-scale resistivity changes downhole. In contrast, dynamic normalization enhances local variations in the hole by rescaling the color binning over $2 \mathrm{~m}$ intervals, windowed over sequential depths throughout the hole. With dynamic normalization it is important to note that unique color bins represent different quantitative values; resistivity relationships from different sections of the hole should not be compared.

\subsection{Dip identification from the images}

GeoFrame $^{\mathrm{TM}}$ analysis software was used to analyze dipping features in Hole 2 (Fig. 6). Flat-lying features appear horizontal on the image, while dipping planar features appear as sinusoids. We fit sinusoids to features and compute dip and dip direction of the features on the GVR6 images. Dip direction is normal to the strike of a feature. Dip directions for layers dipping $\leq 10^{\circ}$ are not included in this analysis owing to the difficulty of assigning a direction to lowangle features.

Each image feature identified in Hole 2 was designated as one of four categories: (1) conductive bed, (2) hydrate-filled bed, (3) conductive fracture, or (4) hydrate-filled fracture. After interpreting 


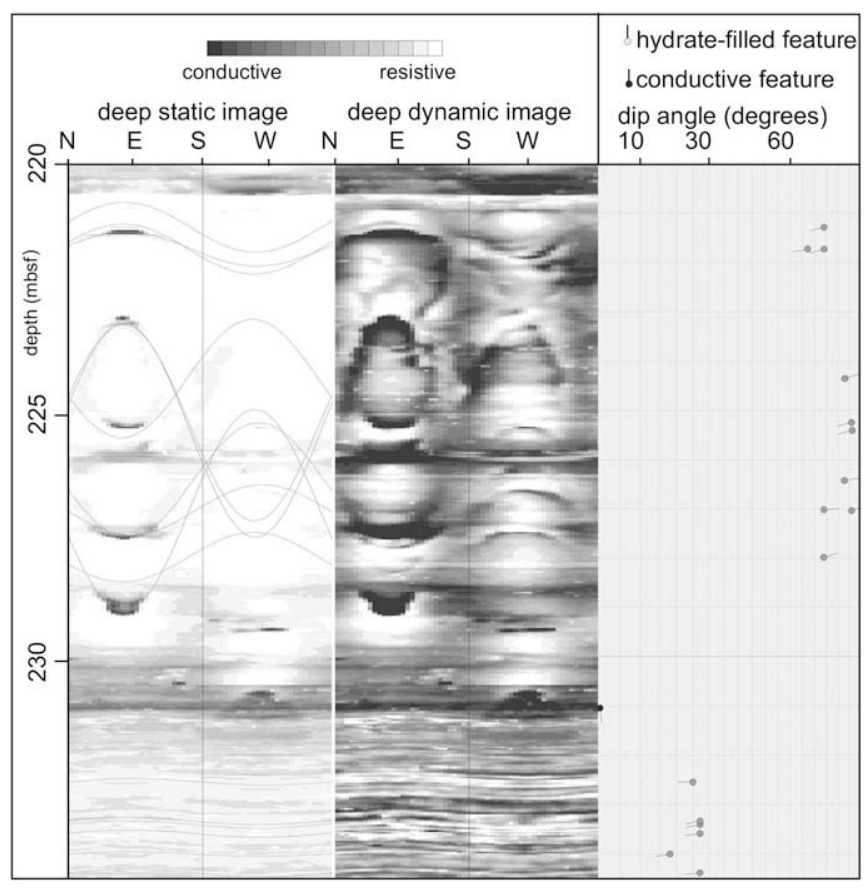

Fig. 6. GeoFrame ${ }^{\mathrm{TM}}$ Borview image from 220 to $234 \mathrm{mbsf}$. This image shows the static (left), dynamic (middle), and dip angle (right). Conductive features appear dark-colored and resistive features appear light-colored on the image. High angle hydrate-filled fractures occur from 220.5 to 229.0 mbsf. Hydrate-filled beds occur from 231 to 234 mbsf.

features in the image, we define beds as features dipping at less than $40^{\circ}$ that do not crosscut lower angle features. On the image, conductive beds appear dark-colored, and hydrate-filled beds appear light-colored.

We define fractures as features that dip at angles $>40^{\circ}$ and that may crosscut beds or other fractures. Conductive fractures appear dark-colored on the image. Hydrate-filled fractures appear lightcolored on the image and often exhibit a halo-like effect. A halo is a white, resistive feature that caps the peak and trough of a sinusoid. Halos are caused by the difference in resistivity between the conductive host sediment and the resistive hydrate, coupled with the influence of a dipping fracture on a lateral investigative tool (Luthi, 2001).

\subsection{Borehole breakouts from the images}

Present-day horizontal stress orientations may be determined from borehole breakouts on the resistivity images (Goldberg and Janik, 2006; McNeill et al., 2004). As a hole is drilled, sediment is flushed out of the hole, and a hoop stress concentration develops around the wellbore. Tangential shear failure occurs if the hoop stress exceeds the formation's compressive strength. This causes spalling, called borehole breakouts, along the borehole wall in the direction of $\mathrm{S}_{\mathrm{Hmin}}$, the minimum horizontal stress direction (Bell and Gough, 1979; Zoback et al., 1985).

GVR6 images detect borehole breakouts even though they do not directly measure the borehole diameter or breakout elongation. Borehole breakouts appear on the GVR6 image due to increased tool standoff from the elongated sides of the ellipse, which lowers the resistivity in the direction of the breakouts (Goldberg and Janik, 2006; McNeill et al., 2004). In Hole 2, borehole breakouts are visible as two separate conductive features running parallel to the vertical axis of the borehole and oriented $180^{\circ}$ apart (Fig. 7). Breakouts are observed in Hole 2 within a few $2-5 \mathrm{~m}$ intervals from 381 to 450 mbsf.

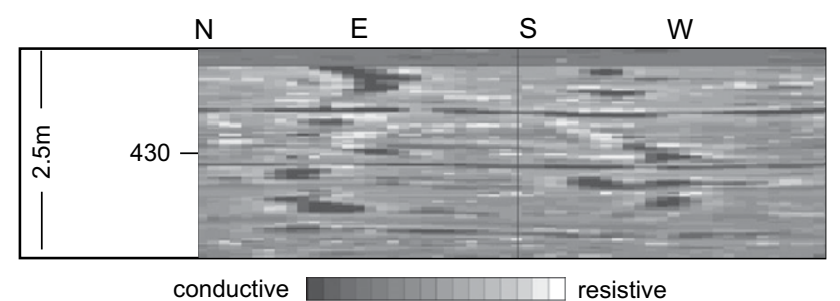

Fig. 7. Borehole breakout at $430 \mathrm{mbsf}$. Borehole breakouts appear as conductive features running parallel to the vertical borehole. They occur in the direction of minimum horizontal stress.

\section{Results}

\subsection{Fractures}

All fractures in Hole 2 dip easterly or westerly, and thus all strike in the $\mathrm{N}-\mathrm{S}$ direction. Fracture aperture is not accurately represented on resistivity images; fractures in this hole are likely on the order of a millimeter or smaller in aperture. A dip plot (Fig. 5) displays the dip and strike of each fracture identified on the borehole images from 180 to 310 mbsf.

We infer that hydrate-filled fractures dominate the fracture system. A few hydrate-filled fractures occur within the sandy clay bed from 110 to 115 mbsf. All other hydrate-filled fractures appear in two intervals from 220 to 250 mbsf and from 260 to 300 mbsf. Fractures observed between 220 and 250 mbsf occur at angles of $>60^{\circ}$. Fractures occurring from 220 to 230 mbsf appear as conjugate sets, dipping both easterly and westerly, which indicates a Mohr-Coulomb fracture mechanism (Jaeger and Cook, 1979). Fractures from 220 to 230 mbsf can be observed in Fig. 6. Hydratefilled fractures between 237 and 250 mbsf dip easterly at angles $>75^{\circ}$. Below $256 \mathrm{mbsf}$, hydrate-filled fractures dip westerly at angles between $40^{\circ}$ and $75^{\circ}$.

Four fractures from 250 to $260 \mathrm{mbsf}$ are dark-colored and were classified as conductive. Three other conductive fractures were identified between 335 to $345 \mathrm{mbsf}$, and each fracture dipped west at $\sim 50^{\circ}$.

\subsection{Beds}

Based on the image data, it is clear that conductive, westerly dipping beds dominate the stratigraphy in Hole 2. The dip of the beds tends to increase downhole and does not exceed $40^{\circ}$. Bedding layers in Hole 2 are interpreted to be the westward dipping hemipelagic drape reflectors observed on the USGS seismic line KC03 (Hutchinson and Hart, 2004).

Some beds in Hole 2 are hydrate-filled. Three high-conductivity intervals where bedding layers appear to contain gas hydrate reside at 109 mbsf, 231-235 mbsf, and 306 mbsf. They fall adjacent to or near hydrate-filled fractures. Hydrate-filled beds between 231 and $235 \mathrm{mbsf}$ are shown in Fig. 6. One small hydrate-filled bed is inferred to occur at $328 \mathrm{mbsf}$; this layer is approximately half a meter thick and not near any hydrate-filled fractures captured in the resistivity image.

\subsection{Horizontal stress orientations}

Fracture orientation can reflect the principal stress directions at the time of fracture formation. Fig. 8 shows the pole of each conductive and hydrate-filled fracture plane in Hole 2 plotted on an equal area stereonet. The linear cluster on the plot shows highangle fracturing and the principal stress directions. Vertical or nearvertical fractures can be expected to strike parallel to $S_{\text {Hmax }}$ (Lawn 


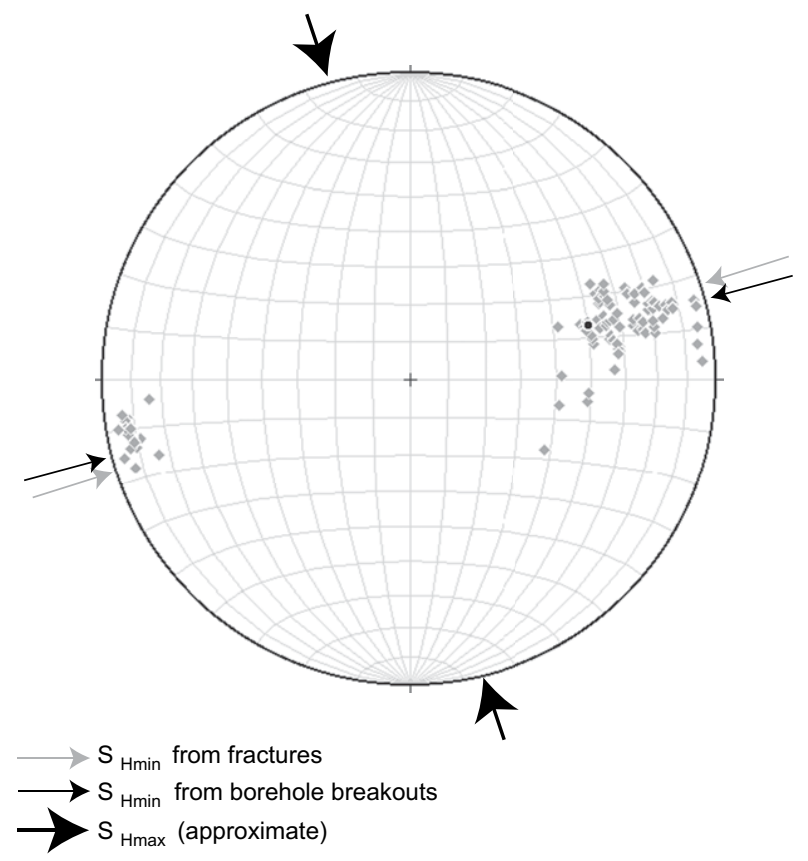

Fig. 8. This equal area stereonet displays the pole to all fracture planes from Hole 2 as gray diamonds. The mean vector of the fractures is plotted as a black circular dot. $\mathrm{S}_{\mathrm{Hmin}}$ determined from the fractures is based on the mean vector and indicated by small gray arrows. Small black arrows indicate $\mathrm{S}_{\mathrm{Hmin}}$ determined from the borehole breakouts. Large black arrows indicate $\mathrm{S}_{\mathrm{Hmax}}, 164^{\circ} \mathrm{SE}-344^{\circ} \mathrm{NW}$. and Wilshaw, 1975; Pollard and Aydin, 1988). Using the mean of the fracture poles, we determine $\mathrm{S}_{\mathrm{Hmin}}$ to be $73^{\circ} \mathrm{NE}-253^{\circ} \mathrm{SW}$ and $\mathrm{S}_{\mathrm{Hmax}}$ to be $163^{\circ} \mathrm{SE}-343^{\circ} \mathrm{NW}$. While borehole breakouts show some azimuthal variability in Hole 2, with the minimum horizontal stress direction $\left(\sigma_{3}\right)$ is oriented approximately $75^{\circ} \mathrm{NE}-255^{\circ} \mathrm{SW}$ and $\mathrm{S}_{\mathrm{Hmax}}$ $\left(\sigma_{2}\right)$ is oriented approximately $165^{\circ} \mathrm{SE}-345^{\circ} \mathrm{NW}$. Overall, the direction of $\mathrm{S}_{\mathrm{Hmax}}$ from the borehole breakouts and the fractures are in agreement. The small difference between the fracture $S_{\mathrm{Hmax}}$ and the breakout $S_{H \max }$ may be attributed to uncertainties in image resolution and interpretation. These results indicate that there has been little (on the order of a few degrees) or no change in the horizontal stress directions from the time of the fracture formation to the date of drilling Hole 2.

\section{Discussion}

\subsection{Local stress regime}

The local topography near Site KC151 is shown in Fig. 9. At Site KC151, $\mathrm{S}_{\mathrm{Hmax}}$ is oriented parallel to the axis of the ridge. The borehole breakouts, which reflect $\mathrm{S}_{\mathrm{Hmin}}$, are oriented normal to the ridge. This local stress regime occurs because the ridge is a structurally strong feature and well supported in the $S_{\mathrm{Hmax}}$ direction, but unsupported in the $S_{\mathrm{Hmin}}$ direction, leading to spalling and mass wasting of sediments downslope. Yassir and Zerwer (1997) used borehole breakouts to study the stress regimes in Green Canyon and Mississippi Canyon in the Gulf of Mexico. They found $\mathrm{S}_{\mathrm{Hmax}}$ oriented E-W, parallel to the edge of the Gulf of Mexico's continental shelf. Thus, stress orientations at Site KC151 are influenced by the local stress regime, not the regional E-W compression, and $\mathrm{S}_{\mathrm{Hmax}}$ is oriented parallel to the local topography.

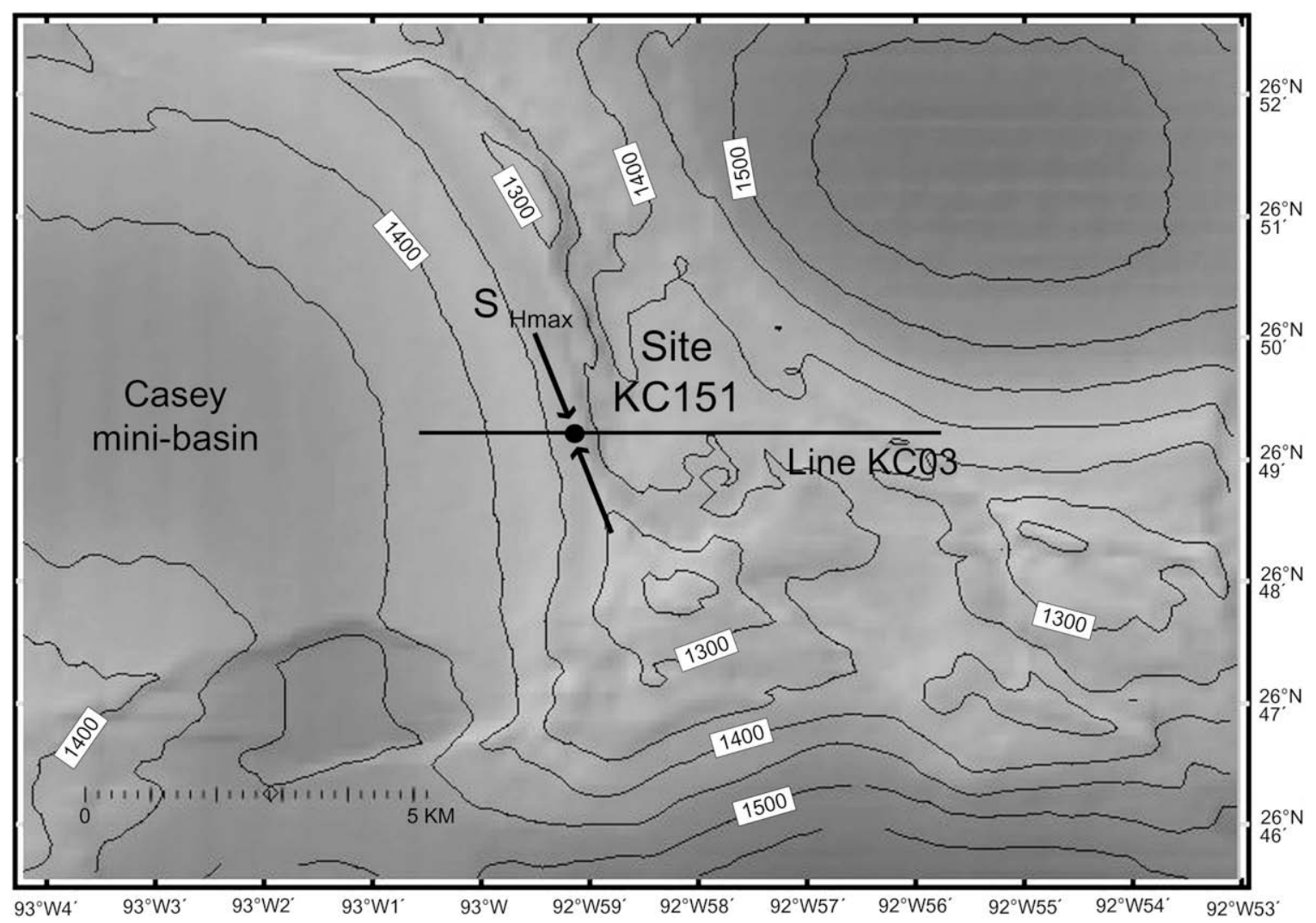

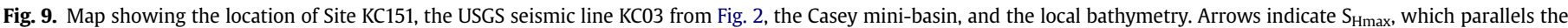
axis of the ridge. Bathymetry is contoured at $50 \mathrm{~m}$ intervals. 


\subsection{Gas dilation and hydrate-forced heave}

Overpressured fluids and gas often cause fracturing in sediments parallel to $S_{\text {Hmax }}$, a phenomenon known as hydro-fracturing (Sibson, 1981). In gas hydrate settings, fracture of sediments associated with free gas migration has been extensively explored using both theoretical approaches and field-based observations (Flemings et al., 2003; Hornbach et al., 2004; Sultan, 2007; Xu and Germanovich, 2004). Hydro-fracturing may be accompanied by dilation, which results in an increase in the bulk formation porosity. Hydrate formation may also cause an increase in porosity by forcing sediment or fractures apart, similar to frost heave. Sassen et al. (2001) hypothesized that gas pressure opens fractures in marine muds, which quickly fill with hydrate. Hydrate formation may continue to increase fracture aperture and force the fracture further apart. Krause (2001) similarly suggests carbon dioxide hydrate forced heave opened parallel relic structures found in a lime mudmound in Nevada, USA. These two mechanisms - gas dilation and hydrate-forced heave - are likely to occur simultaneously, so their effects are difficult to differentiate. Tryon et al. (2002) theorized that gas hydro-fractures the sediment and the fractures line with hydrate, allowing gas to move upward through conduits in the GHSZ, a scenario investigated in further detail by Flemings et al. (2003). As water seeps into such a conduit, more hydrate forms in the conduit interior and reduces permeability. Eventually, gas ceases to flow.

Gas dilation and hydrate forced heave is investigated by examining the relationship between hydrate saturation and density derived porosity. For hydrate saturations computed in Hole 2, the difference between pore water density $\left(1040 \mathrm{~kg} \mathrm{~m}^{-3}\right)$ and hydrate density (nominally $920 \mathrm{~kg} \mathrm{~m}^{-3}$ ) is negligible; only at high gas hydrate saturations does this density contrast become significant. In Hole 2, the two intervals where hydrate occurs display similar saturations but different density porosity values (Fig. 5). Sediment porosity appears unaffected by the hydrate that is inferred to be present within Interval 1, from 220.5 to 250.0 mbsf. Porosity in Interval 1 clearly follows the same compaction trend as watersaturated sediments below 300 mbsf. In Interval 2, from 260.0 to $299.5 \mathrm{mbsf}$, porosity increases with inferred hydrate saturation. The gamma ray log also increases ( $\sim 10$ API) at $253 \mathrm{mbsf}$, indicating a slight increase in clay content, and remains elevated for $\sim 100 \mathrm{~m}$ below this depth. The porosity decreases at $300 \mathrm{mbsf}$, not following the gamma ray trend, and therefore, the porosity change in Interval 2 does not appear to be controlled by clay content, nor by the presence of free gas (see Section 3.3).

Fig. 10 shows a cross plot of porosity and inferred hydrate saturation between 115 and 425 mbsf. A bimodal distribution of porosity in Intervals 1 and 2 is observed. Porosity ranges from $40.5 \%$ to $48.0 \%$ in Interval 1 and from $45.0 \%$ to $52.8 \%$ in Interval 2 . We suggest that the porosity increase in Interval 2 is caused by gas dilation and hydrate-forced heave. Some intervals with high porosities are not associated with these hydrate bearing intervals, such as those near the seafloor in less consolidated sediments. Another location with high porosities is found between Interval 1 and Interval 2, from 250 to 260 mbsf (Fig. 5). However, these porosity values may be in error as the result of a borehole enlarged by $\sim 1.25 \mathrm{~cm}$ at this location.

What mechanism is causing gas dilation and hydrate-forced heave in Interval 2 and not in Interval 1? Similar inferred hydrate saturations are determined for both intervals. Seventy-four hydrate-filled fractures were identified in Interval 2; Interval 1 contains only 24 . Excluding the $4 \mathrm{~m}$ of hydrate-filled beds, the resulting fracture density in Interval 1 is approximately 1 fracture per meter. Porosity values in Interval 1 are consistent with surrounding sediments that do not contain any fractures. Fracture density in Interval 2 is $\sim 1.5$ fractures per meter. It is unlikely that

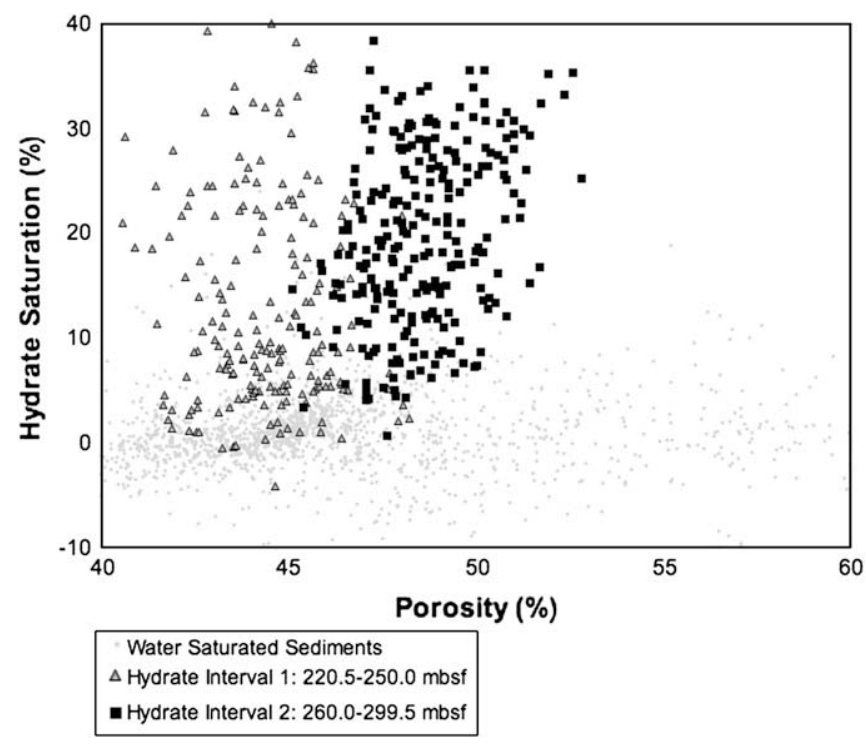

Fig. 10. Porosity vs. inferred hydrate saturation. In Interval 1 (indicated by gray triangles), porosity does not change with hydrate saturation, indicating no influence from dilation or hydrate-forced heave. In Interval 2 (indicated by black squares), porosity increases with hydrate saturation, indicating sediments were forced open by pressured gas and hydrate formation. Water-saturated sediments are indicated by light gray dots, which scatter about zero hydrate saturation. Data in the enlarged interval from 0 to 115 mbsf are not included.

fracture density increases porosity by $5 \%$ in Interval 2 when 1 fracture per meter has no notable effect on porosity elsewhere. Thus, we conclude that fracture density does not significantly control porosity in these intervals.

One explanation for the observed $5 \%$ difference in porosity between Interval 1 and 2 rests on the different mechanisms that may have caused the fractures to form initially. Fractures formed in Interval 1 may be the result of buckling due to local salt intrusion. Hydro-fracturing may have initiated the formation of fractures in Interval 2. Although gas dilation may occur simultaneously with hydro-fracturing, hydrate-forced heave can occur with or without hydro-fracturing. Thus, if present, elevated porosity due to hydrate-forced heave should be observed in all intervals containing gas hydrate filled fractures. Because the increased porosity is only observed in Interval 2, dilation likely has a larger effect on porosity than hydrate-forced heave in this environment.

\subsection{Fracture-controlled hydrate model}

Gas hydrate appears to form at site KC151 primarily in two modes: (1) filling open fractures and (2) filling permeable beds. At Site KC151, we postulate that gas likely migrated through open fractures driven by buoyancy forces. Gas hydrate resides largely in the fractures due to the impermeability of water-saturated clays (Harrington and Horseman, 1999). In a few locations, where formation permeability is high, natural gas may move from fracture conduits into permeable bedding layers, forming hydrate within those layers (Fig. 11).

Using the resistivity images from Hole 2, we infer hydrate-filled beds at $109 \mathrm{mbsf}, 231-235 \mathrm{mbsf}$, and 306 mbsf that appear adjacent or near hydrate-filled fractures. These observations support the idea of gas flowing through high permeability fractures and into high permeability beds. One small layer inferred to be filled with hydrate occurs at 328 mbsf far from any hydrate-filled fractures. This layer may be a laterally extensive hydrate-filled bed, 


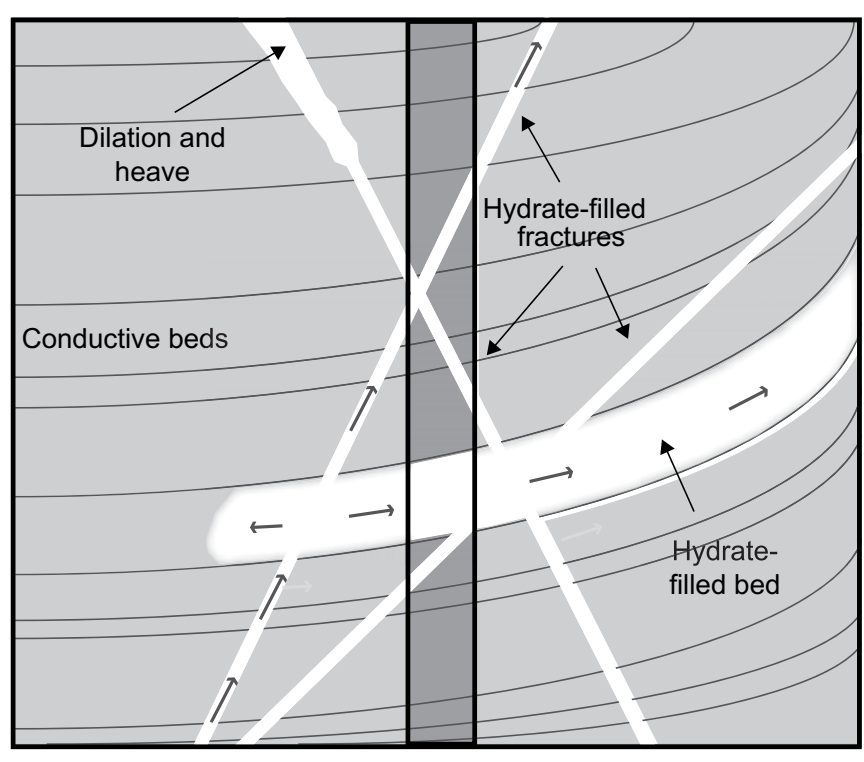

direction of gas movement

Fig. 11. Fracture-controlled hydrate model. This model depicts the modes of hydrate occurrence observed in Hole 2. Hydrate-filled fractures are shown intersecting the well (center). Gas that supplied the fractures may travel into permeable bedding layers, forming hydrate filled beds. Gas dilation and hydrate-forced heave may cause fractures to open, causing an increase in bulk porosity.

or the bed may be fed by a nearby fracture that did not intersect Hole 2.

Site KC151 is interpreted to contain more than $50 \mathrm{~m}$ of hydrate bearing sediments with saturations $>20 \%$. The inferred hydrate show is significant when compared with other well-documented marine gas hydrate accumulations (Paull et al., 1996; Tréhu et al., 2003; Riedel et al., 2005). Other continental margin settings with significant fracture networks and sufficient sources of gas may also contain significant concentrations of gas hydrate. More information about the 3-D distribution of fracturing near Site KC151-2, however, will be needed in order to determine and quantify the extent of hydrate saturation in this region.

\section{Conclusions}

Evaluation of hydrate distribution from the borehole resistivity images in Keathley Canyon KC151-2 indicates that the fracture system controls hydrate distribution. We infer that: (1) hydrate forms primarily within the fractures and not in beds; (2) natural gas may prefer to move along the relatively more permeable fracture system rather than through the surrounding sediment; (3) the fracture system is a result of the local stress regime; and (4) gas dilation and hydrate-forced heave may cause an increase in bulk sediment porosity in hydrate saturated sediments.

\section{Acknowledgements}

We thank C. Broglia and T. Williams for their help with GeoFrame $^{\mathrm{TM}}$ (Mark of Schlumberger) processing of the well log data, and A. Malinverno for collaborating on hydrate saturation estimates using numerical methods. We also thank the creators of the mapping and analysis programs, Geomapapp and Stereonet for Macintosh, both used in this research, available at www.geomapapp.org and http://www.geo.cornell.edu/geology/faculty/RWA/.

\section{References}

Archie, G.E., 1942. The electrical resistivity log as an aid in determining some reservoir characteristics. Petr. Trans. AIME 146, 54-62.

Beauboeuf, R.T., Friedmann, S.J., 2000. High-resolution seismic/sequence stratigraphic framework for the evolution of Pleistocene intraslope basins. Western Gulf of Mexico: depositional models and reservoir analogs. In: GCSSEPM Foundation 20th Annual Research Conference, Deepwater reservoirs of the world, pp. 40-60.

Bell, J.S., Gough, D.I., 1979. Northeast-southwest compressive stress in Alberta evidence from oil wells. Earth Planet Sci. Lett. 45, 475-482.

Bonner, S., Fredette, M., Lovell, J., Montaron, B., Rosthal, R., Tabanou, J., Wu, P., Clark, B., Mills, R., Williams, R., 1996. Resistivity while drilling - images from the string. Oilfield Rev. 8, 4-19.

Claypool, G.E. (Ed.), 2006. Cruise Report: The Gulf of Mexico Gas Hydrate Joint Industry Project, Covering the Cruise of the Drilling Vessel Uncle John, Mobile, Alabama to Galveston, Texas, Atwater Valley Blocks 13/14 and Keathley Canyon Blocks 151, 17 April to 22 May, 2005. Department of Energy. http://www.netl. doe.gov/technologies/oil-gas/publications/Hydrates/reports/GOMJIPCruise05. pdf, 196 pp.

Collett, T.S., Ladd, J., 2000. Detection of gas hydrate with downhole logs and assessment of gas hydrate concentrations (saturations) and gas volumes on the Blake Ridge with electrical resistivity log data. In: Paull, C.K., Matsumoto, R., Wallace, P.J., Dillion, W.P. (Eds.), Proceedings of ODP, Scientific Results, 164. http://owen.nhm.ac.uk/odp/publications/164_SR/VOLUME/CHAPTERS/SR164_ 19.PDF.

Dai, J., Snyder, F., Gillespie, D., Koesoemadinata, A., Dutta, N., 2008. Exploration for gas hydrates in the deepwater northern Gulf of Mexico: Part I. A seismic approach based on geologic model, inversion, and rock physics principals. Mar. Petr. Geol. 25, 845-859.

Dugan, B., 2008. Fluid flow in the Keathley Canyon 151 mini-basin, northern Gulf of Mexico. Mar. Petr. Geol. 25, 919-923.

Erickson, S.N., Jarrard, R.D., 1998. Porosity/formation-factor relationships for high-porosity siliciclastic sediments from Amazon Fan. Geophys. Res. Lett. 25, 2309-2312.

Flemings, P.B., Liu, X.L., Winters, W.J., 2003. Critical pressure and multiphase flow in Blake Ridge gas hydrates. Geology 31, 1057-1060.

Goldberg, D., Janik, A., 2006. Data report: Stress orientation in gas hydrate-bearing sediments near Hydrate Ridge: evidence from borehole breakouts observed from logging-while-drilling resistivity images. In: Tréhu, A.M., Bohrmann, G., Torres, M.E., Colwell, F.S. (Eds.), Proceedings of ODP, Scientific Results, 204. http://www-odp.tamu.edu/publications/204_SR/108/108.htm.

Hamilton, E.L., 1976. Variations of density and porosity with depth in deep-sea sediments. J. Sed. Pet. 46, 280-300.

Harrington, J.F., Horseman, S.T., 1999. Gas transport properties of clays and mudrocks. In: Aplin, A.C., Fleet, A.J., Macquaker, J.S. (Eds.), Muds and Mudstones: Physical and Fluid Flow Properties. Geological Society, London, pp. 107-124.

Hippe, F.W., Humphrey, G.D., Tjok, K.-M., 2006. Geotechnical Investigation, Chevron GOM Gas Hydrates JIP, Report No. 0201-5081. http://www.netl.doe.gov/technologies/oil-gas/FutureSupply/MethaneHydrates/MH_ReferenceShelf/RefShelf. html.

Hornbach, M.J., Saffer, D.M., Steven Holbrook, W., 2004. Critically pressured free-gas reservoirs below gas-hydrate provinces. Nature 427, 142-144.

Hutchinson, D.R., Hart, P.E., 2004. Cruise report for G1-03-GM USGS gas hydrates cruise, R/V Gyre, 1-14 May, 2003. Open-File Report OF 03-474. US Geological Survey, Northern Gulf of Mexico, 103 pp.

Hutchinson, D.R., Hart, P.E., Collett, T.S., Edwards, K.M., Twichell, D.C., Snyder, F., 2008. Geologic framework of the 2005 Keathley Canyon gas hydrate research well, northern Gulf of Mexico. Mar. Petr. Geol. 25, 906-918.

Hutchinson, D.R., Hart, P.E., Ruppel, C.D., Snyder, F., Dugan, B., 2008. Seismic and thermal characterization of a bottom simulating reflection in the northern Gulf of Mexico. In: Collett, T.S., Johnson, A., Knapp, C., Boswell, R. (Eds.), Natural Gas Hydrates: Energy Resources, Potential and Associated Geologic Hazards. AAPG Special Publication.

Jaeger, J.C., Cook, N.G.W., 1979. Fundementals of Rock Mechanics, third ed. Chapman and Hall, New York, 593 pp.

Kastner, M., Claypool, G., Robertson, G., 2008. Geochemical constraints on the origin of the pore fluids and gas hydrate distribution at Atwater Valley and Keathley Canyon, Northern Gulf of Mexico. Mar. Petr. Geol. 25, 860-872.

Kleinberg, R.L., 2008. Exploration strategy for economically significant accumulations of marine gas hydrate. In: Sediment-hosted Gas Hydrates: New Insights on Natural and Synthetic Systems. Geological Society of London Special Publications.

Krause, F.F., 2001. Genesis and geometry of the Meiklejohn Peak lime mud-mound, Bare Mountain Quadrangle, Nevada, USA: Ordovician limestone with submarine frost heave structures - a possible response to gas clathrate hydrate evolution. Sediment. Geol. 145 (3-4), 189-213.

Kvenvolden, K., Barnard, L., 1982. Hydrates of natural gas in continental margins. AAPG Memoir 34.

Lawn, B.R., Wilshaw, T.T., 1975. Fracture of Brittle Solids. Cambridge University Press, Cambridge, 204 pp.

Lee, M., Collett, T., 2008. Integrated analysis of well logs and seismic data to estimate gas hydrate concentrations at Keathley Canyon, Gulf of Mexico. Mar. Petr. Geol. 25, 924-931.

Luthi, S.M., 2001. Geological Well Logs. Springer, New York, 373 pp. 
Malinverno, A., Kastner, M., Torres, M.E., Wortmann, U.G., 2008. Gas hydrate occurrence from pore water chlorinity and downhole logs in a transect across the northern Cascadia Margin (IODP Exp. 311) , J. Geophys. Res. in press, doi: 10. 1029/2008JB005702.

Markl, R.G., Bryan, G.M., Ewing, J.I., 1970. Structure of the Blake-Bahama outer ridge. J. Geophys. Res. 75, 4539-4555.

McNeill, L.C., Ienaga, M., Tobin, H., Saito, S., Goldberg, D., Moore, J.C., Mikada, H. 2004. Deformation and in situ stress in the Nankai Accretionary Prism from resistivity-at-bit images, ODP Leg 196. Geophys. Res. Lett. 31, L02602, doi:10. 1029/2003GL018799.

Milkov, A.V., Sassen, R., 2001. Estimate of gas hydrate resource, northwestern Gulf of Mexico continental slope. Mar. Geol. 179, 71-83.

Moscardelli, L., Wood, L., Mann, P., 2006. Mass-transport complexes and associated processes in the offshore area of Trinidad and Venezuela. AAPG Bull. 90,1059-1088.

Murray, D., Kleinberg, R.L., Sinha, B., Fukuhara, M., Osawa, O., Endo, T., Namikawa, T. 2006. Formation evaluation of gas hydrate reservoirs. Petrophysics 47, 129-137.

Nelson, T.H., 1991. Chapter 5: salt tectonics and listric normal faulting. In: Salvador, A. (Ed.), The Gulf of Mexico Basin. The Geology of North America, vol. J. GSA, Boulder, CO, pp. 73-89.

Nimblett, J., Ruppel, C., 2003. Permeability evolution during the formation of gas hydrates in marine sediments. J. Geophys. Res. 108, 2420, doi:10.1029/ 2001JB001650.

Paull, C.K., Matsumoto, R., Wallace, P.J., 1996. Gas hydrate sampling on the Blake Ridge and Carolina Rise. In: Proceedings of ODP, Initial Reports. Ocean Drilling Program, 164, College Station, TX.

Pollard, D.D., Aydin, A., 1988. Progress in understanding jointing over the past century. Geol. Soc. Amer. Bull. 100, 1181-1204.

Prather, B.E., Booth, J.R., Steffens, G.S., Craig, P.A., 1998. Classification, lithologic calibration, and stratigraphic succession of seismic facies of intraslope basins, deep-water Gulf of Mexico. AAPG Bull. 82, 701-728.

Pratson, L.F., Ryan, W.B.F., 1994. Pliocene to Recent infilling and subsidence of intraslope basins offshore Louisiana. AAPG Bull. 78, 1483-1506.

Riedel, M., Collett, T.S., Malone, M.J., Expedition 311 Scientists, 2005. Cascadia margin gas hydrates. In: Proceedings of IODP, 311, College Station, TX.

Sassen, R., Losh, S.L., Cathles, L., Roberts, H.H., Whelan, J.K., Milkov, A.V., Sweet, S.T. DeFreitas, D.A., 2001. Massive vein-filling gas hydrate: relation to ongoing gas migration from the deep subsurface in the Gulf of Mexico. Mar. Petr. Geol. 18, 551-560.

Sassen, R., Sweet, S.T., DeFreitas, D.A., Milkov, A.V., Salata, G., McDade, E.W., 1999. Geology and geochemistry of gas hydrates, Central Gulf of Mexico continental slope. Gulf Coast Assoc. Geol. Soc. Trans. 49, 462-468.

Sibson, R.H., 1981. Controls on low-stress hydro-fracture dilatancy in thrust, wrench and normal fault terrains. Nature 289, 665-667.

Sultan, N., 2007. Comment on "Excess pore pressure resulting from methane hydrate dissociation in marine sediments: A theoretical approach" by Wenyue Xu and Leonid N. Germanovich. J. Geophys. Res. 112, B02103, doi:10.1029/ 2006JB004527.

Tishchenko, P., Hensen, C., Wallmann, K., Wong, C.S., 2005. Calculation of the stability and solubility of methane hydrate in seawater. Chem. Geol. 219, 37-52.

Tréhu, A.M., Bohrmann, G., Torres, M.E., Colwell, F.S. (Eds.), 2003. Drilling Gas Hydrates on Hydrate Ridge, Cascadia Contiental Margin, Proceedings of ODP, Initial Reports, 204. Ocean Drilling Program, College Station, TX.

Tréhu, A.M., Flemings, P.B., Bangs, N.L., Chevallier, J., Gràcia, E., Johnson, J.E., Liu, C.S., Liu, X., Riedel, M., Torres, M.E., 2004. Feeding methane vents and gas hydrate deposits at south Hydrate Ridge. Geophys. Res. Lett. 31, L23310.

Tryon, M.D., Brown, K.M., Torres, M.E., 2002. Fluid and chemical flux in and out of sediments hosting methane hydrate deposits on Hydrate Ridge, OR, II: hydrological processes. Earth Planet Sci. Lett. 201, 541-557.

Weinberger, J.L., Brown, K.M., 2006. Fracture networks and hydrate distribution at Hydrate Ridge, Oregon. Earth Planet Sci. Lett. 245, 123-136.

Woodbury, H.O., Murray, I.B., Pickford, P.J., Akers, W.H., 1973. Pliocene and Pleistocene depocenters, outer continental-shelf, Louisiana and Texas. AAPG Bull. 57, 2428-2439.

Xu, W., Germanovich, L.N., 2004. Excess pore pressure resulting from methane dissociation in marine sediments: a theoretical approach. J. Geophys. Res. 111, B01104, doi:10.1029/2004JB003600.

Yassir, N.A., Zerwer, A., 1997. Stress regimes in the Gulf Coast, offshore Louisiana; data from well-bore breakout analysis. AAPG Bull. 81, 293307.

Zoback, M.D., Moos, D., Mastin, L., 1985. Well bore breakouts and in situ stress. J. Geophys. Res. 90, 5523-5530. 